\title{
Correction to: From legacy pollutants to emerging contaminants: recent inputs from the 2018 conference of EcoBIM network
}

\author{
Michel Auffret ${ }^{1} \cdot$ Jérôme Cachot ${ }^{2} \cdot$ Richard Saint-Louis $^{3}$
}

Published online: 27 January 2020

(C) Springer-Verlag GmbH Germany, part of Springer Nature 2020

Correction to: Environmental Science and Pollution Research https://doi.org/10.1007/s11356-020-07636-4

The original publication of this paper contains a mistake.

The correct title is shown in this paper.

The original article was corrected.

The online version of the original article can be found at https://doi.org/ $10.1007 / \mathrm{s} 11356-020-07636-4$

\footnotetext{
Jérôme Cachot

jerome.cachot@u-bordeaux.fr

1 Environmental Toxicology, European Institute for Marine Studies IUEM, Brest University, Brest, France

2 Laboratory Environnements et Paléoenvironnements Océaniques et Continentaux, EPOC, UMR 5805 CNRS-University of Bordeaux, Bordeaux, France

3 Environmental Chemistry, University du Québec, Rimouski, Canada
} 